Article

\title{
Diagnosing Organic Causes of Schizophrenia Spectrum Disorders: Findings from a One-Year Cohort of the Freiburg Diagnostic Protocol in Psychosis (FDPP)
}

\author{
Dominique Endres 1,2, Miriam Matysik ${ }^{1,2}$, Bernd Feige ${ }^{1,2}{ }^{10}$, Nils Venhoff ${ }^{3}$, Tina Schweizer ${ }^{1,2}$, \\ Maike Michel ${ }^{2}$, Sophie Meixensberger ${ }^{1,2}$, Kimon Runge 1,2 $\oplus$, Simon J. Maier 1,2, \\ Kathrin Nickel ${ }^{1,2}$, Karl Bechter ${ }^{4}$ (D) Horst Urbach ${ }^{5}$, Katharina Domschke ${ }^{2,6}$ \\ and Ludger Tebartz van Elst $1,2, *$ (D) \\ 1 Section for Experimental Neuropsychiatry, Department of Psychiatry and Psychotherapy, Medical \\ Center-University of Freiburg, Faculty of Medicine, University of Freiburg, 79104 Freiburg, Germany; \\ dominique.endres@uniklinik-freiburg.de (D.E.); miriam.matysik@uniklinik-freiburg.de (M.M.); \\ bernd.feige@uniklinik-freiburg.de (B.F.); tina.schweizer@uniklinik-freiburg.de (T.S.); \\ sophie.marie.meixensberger@uniklinik-freiburg.de (S.M.); kimon.runge@uniklinik-freiburg.de (K.R.); \\ simon.maier@uniklinik-freiburg.de (S.J.M.); kathrin.nickel@uniklinik-freiburg.de (K.N.) \\ 2 Department of Psychiatry and Psychotherapy, Medical Center-University of Freiburg, Faculty of Medicine, \\ University of Freiburg, 79104 Freiburg, Germany; maike.michel@uniklinik-freiburg.de (M.M.); \\ katharina.domschke@uniklinik-freiburg.de (K.D.) \\ 3 Department of Rheumatology and Clinical Immunology, Medical Center-University of Freiburg, \\ Faculty of Medicine, University of Freiburg, 79106 Freiburg, Germany; nils.venhoff@uniklinik-freiburg.de \\ 4 Department for Psychiatry and Psychotherapy II, Ulm University, Bezirkskrankenhaus Günzburg, \\ 89312 Günzburg, Germany; karl.bechter@bkh-guenzburg.de \\ 5 Department of Neuroradiology, Medical Center-University of Freiburg, Faculty of Medicine, \\ University of Freiburg, 79106 Freiburg, Germany; horst.urbach@uniklinik-freiburg.de \\ 6 Center for Basics in Neuromodulation, Faculty of Medicine, University of Freiburg, 79106 Freiburg, Germany \\ * Correspondence: tebartzvanelst@uniklinik-freiburg.de
}

Received: 27 July 2020; Accepted: 3 September 2020; Published: 14 September 2020

\begin{abstract}
Introduction: Secondary schizophrenia spectrum disorders (SSDs) have clearly identifiable causes. The Department for Psychiatry and Psychotherapy at the University Hospital Freiburg has continued to expand its screening practices to clarify the organic causes of SSDs. This retrospective analysis was carried out to analyze whether a comprehensive organic diagnostic procedure could be informative in patients with SSDs. Methods and Participants: The "Freiburg Diagnostic Protocol in Psychosis" (FDPP) included basic laboratory analyses (e.g., thyroid hormones), metabolic markers, pathogens, vitamin status, different serological autoantibodies, rheumatic/immunological markers (e.g., complement factors), cerebrospinal fluid (CSF) basic and antineuronal antibody analyses, as well as cranial magnetic resonance imaging (cMRI) and electroencephalography (EEG). The findings of 76 consecutive patients with SSDs (55 with paranoid-hallucinatory; 14 with schizoaffective; 4 with hebephrenic; and 1 each with catatonic, acute polymorphic psychotic, and substance-induced psychotic syndromes) were analyzed. Results: Overall, vitamin and trace element deficiency was identified in $92 \%$. Complement factor analyses detected reduced C3 levels in $11 \%$. Immunological laboratory alterations were detected in $76 \%$. CSF analysis revealed general alterations in $54 \%$ of the patients, mostly with signs of blood-brain barrier dysfunction. cMRI analyses showed chronic inflammatory lesions in $4 \%$. Combination of EEG, cMRI, and CSF revealed alterations in $76 \%$ of the patients. In three patients, autoimmune psychosis was suspected (4\%). Discussion: On the basis of these findings, we conclude that a comprehensive diagnostic procedure according to the FDPP in patients with SSD is worthwhile, considering the detection of secondary, organic forms of SSDs, as well
\end{abstract}


as alterations in "modulating factors" of the disease course, such as vitamin deficiency. Larger studies using comprehensive diagnostic protocols are warranted to further validate this approach.

Keywords: schizophrenia; psychosis; autoimmune psychosis; screening; antibody; cerebrospinal fluid; EEG; MRI

\section{Introduction}

Schizophrenia spectrum disorders (SSDs) are characterized by delusions, hallucinations, disorganized speech, affective flattening, and cognitive deficits that are linked to significant disability and psychosocial impairment. They also are associated with psychosocial stigma and discrimination [1-3]. In primary, idiopathic forms of SSDs, examination findings are typically inconspicuous, and a genetic liability is assumed [4,5]. However, secondary schizophrenia spectrum disorders (SSSDs) have clearly identifiable organic causes and can occur in the context of central autoimmune (e.g., autoimmune encephalitis, autoimmune psychosis) or systemic autoimmune (e.g., systemic lupus erythematosus), infectious (e.g., neuroborreliosis, neurosyphilis), endocrine (e.g., hyperthyroidism, hyperparathyroidism), metabolic (e.g., Wilson's disease, metachromatic leukodystrophy), epileptic (e.g., temporal lobe epilepsy), cerebrovascular (e.g., strategic infarcts), genetic (e.g., velocardiofacial syndrome, Niemann—Pick disease type C), tumor-related (e.g., gliomas), neurodegenerative (e.g., Huntington's disease), substance-related (e.g., cannabis, phencyclidine), or dietary-related (e.g., vitamin B12 deficiency) diseases [6]. In addition to clinical evaluation, a number of other examinations are available to investigate secondary causes. The most frequently used are blood analyses (for testing antineuronal antibody or hormone levels, karyotyping, etc.), urine examinations (drug screening, markers for porphyria, etc.), structural imaging (cranial magnetic resonance imaging (cMRI), etc.), electroencephalography (EEG; routine/sleep EEG, etc.), and cerebrospinal fluid (CSF) analyses (basic diagnostics, antibody/pathogen detection, etc.). In the case of specific suspicion, further examinations, such as neuronuclear methods $\left(\left[18^{\mathrm{F}}\right]\right.$ fluorodeoxyglucose positron emission tomography (FDG-PET), etc.); electrophysiological examinations (evoked potentials, etc.); or, more rarely, invasive methods (brain biopsies, etc.) can be performed [7]. Country-specific guidelines provide recommendations on which diagnostic regime should be used to exclude secondary causes. The German S3 guideline recommends obligatory complete physical and neurological examinations, several blood tests (e.g., C-reactive protein (CRP) or thyroid parameters), drug screening in urine, and cMRI. CSF and EEG analyses, as well as further blood examinations (e.g., for brain-reactive autoantibodies), are suggested in cases of specific suspicion based on clinical findings and baseline examinations [8]. In recent years, increased emphasis has been put on the detection of autoimmune encephalitis and autoimmune psychoses, in particular, as differential diagnosis for SSDs [7,9-11]. As affected patients frequently respond to treatment with anti-inflammatory drugs, an optimal and early diagnosis is essential [7]. Following our experiences that secondary, organic psychoses cannot always be reliably differentiated from primary, idiopathic variants on the basis of the baseline examinations mentioned above [5,12-15], the Department of Psychiatry and Psychotherapy at the University Hospital Freiburg, Germany, has been continuously expanding and refining its diagnostic protocol of screening for organic causes of psychotic disorders ("Freiburg Diagnostic Protocol of Psychoses" (FDPP)). Since 2018, patients on the specialized ward of the Department of Psychiatry and Psychotherapy, University of Freiburg, have been offered broad laboratory screening, as well as cMRI, EEG, and CSF analysis.

\section{Rationale of the Current Study}

The FDPP extends far beyond the current German S3 and other guidelines' recommendations. The present retrospective analysis was performed to analyze whether such a broad organic screening is 
acceptable to patients and whether it is informative in all patients with SSDs. Moreover, we wanted to test whether or not the respective findings from such an extensive diagnostic procedure might justify the efforts or alternatively support the foreseeable criticism that this diagnostic protocol is exaggerated. The main hypothesis of our retrospective workup was that, first, autoimmune psychoses and other organic forms can be detected using the FDPP, and second, a relevant number of alterations can be found in disease-modulating factors, such as neurovitamins.

\section{Materials and Methods}

In 2018, 76 patients over 18 years who suffered from SSDs were examined on the specialized ward for psychoses, autism spectrum disorders, and organic psychiatric disorders. Data of these patients were retrospectively analyzed in the current project, which was approved by the local ethics committee (Faculty of Medicine, University of Freiburg, ethical vote no. 396/18).

\subsection{Patient Cohort}

A search was made for patients with the following diagnoses (classified by experienced senior psychiatrists according to the criteria of the International Classification of Diseases, 10th revision), who were treated on our special ward in 2018: organic delusional (schizophrenia-like) disorder (F06.2), substance-induced psychotic disorder (F1x.5), schizophrenia (F20.x), persistent delusional disorders (F22.x), acute and transient psychotic disorders (F23.x), and schizoaffective disorders (F25.x; https://www.who.int/classifications/icd/en/GRNBOOK.pdf?ua=1). For further analysis, the patients were grouped according to their predominating clinical syndrome. The categorization was made in terms of paranoid-hallucinatory, schizoaffective, hebephrenic, catatonic, acute polymorphic psychotic, substance-induced psychosis, and delusional syndromes. We also distinguished between acute and relapsing/chronic forms of the disease. The 76 patients included in this study suffered from the following syndromes: 55 (72\%) from paranoid-hallucinatory, 14 (18\%) from schizoaffective, $4(5 \%)$ from hebephrenic, $1(1 \%)$ from catatonic, $1(1 \%)$ from acute polymorphic psychotic, and $1(1 \%)$ from substance-induced psychosis syndromes; no patient suffered from a delusional syndrome ( $0 \%)$. A total of 15 patients were investigated during the first episode $(20 \%)$, and 61 cases had a chronic or recurrent disorder $(80 \%)$.

\subsection{Blood and Cerebrospinal Fluid Analyses}

The investigations carried out are summarized in Table 1. Blood examinations were performed according to established methods and as part of clinical routine. Most analyses were performed in the Central Laboratory of the University Hospital Freiburg. Blood tests were performed in all 76 patients, but not all parameters were carried out in each patient during clinical work-up. CSF analyses were performed in the CSF laboratory of the Department of Neurology of the University Hospital Freiburg in accordance with international recommendations [16]. Tests for antibodies against neuronal cell surface antigens and anti-AQP4/MOG antibodies were performed using fixed cell biochip assays from Euroimmun ${ }^{\circledR}$. The antineuronal antibodies against intracellular antigens were investigated using Ravo line assays ${ }^{\circledR}$. Anti-glutamate decarboxylase (GAD) 65 antibodies were also tested using radioimmunoassay (RIA). Methods for rheumatic testing and CSF basic analyses are described in earlier papers from our working group [14,17]. CSF analyses were performed in 48 of the 76 patients (63\%) in 2018.

\subsection{Electroencephalography}

EEGs were performed in all 76 patients $(100 \%)$, while MRI investigations of the brain were carried out in 74 patients (97\%) (Table 1). EEG findings were evaluated by the physician responsible for the respective patient and alterations were retrospectively coded as one of the following: continuous generalized slow activity, continuous regional slow activity, intermittent rhythmic generalized delta/theta activity (IRDAs/IRTAs), intermittent regional slow activity, or epileptic activity. The EEGs 
were also evaluated automatically and examined for IRDAs/IRTAs. The methodology has been described in detail in earlier papers [18,19].

\subsection{Cerebral Magnetic Resonance Imaging}

We routinely acquired T1-weighted (axial $5 \mathrm{~mm}$ thick fast spin echo slices on a 1.5 Tesla, magnetization prepared rapid gradient echo (MPRAGE) sequences with isotropic $1 \mathrm{~mm}^{3}$ voxels on a 3 Tesla scanner), diffusion-weighted imaging (DWI) (axial $5 \mathrm{~mm}$ thick slices), and fluid-attenuated inversion recovery (FLAIR) sequences (coronal $3 \mathrm{~mm}$ thick fast spin echo slices on a 1.5 Tesla, 3D SPACE sequence with isotropic $1 \mathrm{~mm}^{3}$ voxels on a 3 Tesla scanner). The MPRAGE sequence is routinely used for voxel-based analysis and thus helps to detect regional atrophy. The FLAIR sequence is needed to detect increased signal intensity, particularly of the mesiotemporal structures that are often also swollen in limbic encephalitis. DWI may detect acute or subacute (strategic) infarcts and is the most sensitive sequence for the diagnosis of Creutzfeldt-Jakob disease. All cMRIs were evaluated by experienced neuroradiological specialists. The cMRI alterations were divided into five categories: white matter (WM) changes (with any small, non-specific WM lesion rated as an alteration), (chronic) inflammatory lesions, atrophy (local or generalized), pineal cysts, and others.

\subsection{Statistics}

The data analysis was performed using SPSS, version 24 (IBM, New York, NY, USA). The findings were mainly reported descriptively. The rate of pathological values was based on established reference values. In addition, a Pearson correlation between CSF basic parameters (white blood cell (WBC) count, protein concentration, albumin quotient, and immunoglobulin (Ig) $G$ index) and IRDA/IRTA rates was performed. A $p$-value of $<0.05$ was assumed to be significant. Due to the exploratory approach, no correction for multiple testing was performed. 
Table 1. Screening approach in patients with schizophrenia spectrum disorders.

\begin{tabular}{|c|c|c|c|}
\hline & & Freiburg FDPP Screening & Additional Analyses in Selected Cases \\
\hline \multirow{5}{*}{ Extended basic laboratory analyses } & Blood count & - Differential blood count & - Acanthocytes $^{1}$ \\
\hline & Coagulation & - INR/Quick, PTT & - Lupus anticoagulant ${ }^{2}$ \\
\hline & Electrolytes & $\begin{array}{l}\text { - Sodium, potassium, calcium, } \\
\text { magnesium }\end{array}$ & \\
\hline & Metabolic markers & $\begin{array}{l}\text { - Creatinine, CK, GOT, GPT, AP, } \gamma-\mathrm{GT} \text {, } \\
\text { lipase } \\
\text { - HbA1C, total triglycerides, total } \\
\text { cholesterol, homogeneous LDL } \\
\text { cholesterol, homogeneous HDL } \\
\text { cholesterol } \\
\text { Alpha-galactosidase }^{3}\end{array}$ & $\begin{array}{l}\text { - Parathyroid hormone }{ }^{4} \text {, phosphate; } \\
\text { ceruloplasmin }{ }^{5} \text {, copper; bilirubin } \\
\text { - Arylsulfatase activity }{ }^{6} \text {, homocysteine, } \\
\text { long-chain fatty acids }{ }^{7} \text {, chitotriosidase } \\
\text { activity }{ }^{8} \\
\text { - Mutation analysis in NPC1/2 gene }{ }^{8} \text {, } \\
\text { mutation search, and MLPA analysis } \text { GLA gene } \\
\end{array}$ \\
\hline & Thyroid hormones & $-\mathrm{TSH}$, free T3, free T4 & \\
\hline \multirow[t]{2}{*}{ Vitamins/trace elements } & Vitamins & $\begin{array}{l}\text { - Vitamin D } \\
\text { - Folic acid (vit. B9), cobalamin (vit. B12) }\end{array}$ & $\begin{array}{l}\text { - Thiamine (vit. B1), niacin (vit. B3), } \\
\text { pyridoxine (vit. B6) } \\
\text { - Holotranscobalamin, methylmalonic } \\
\text { acid }\end{array}$ \\
\hline & Trace elements & - Selenium & - Zinc \\
\hline Pathogens & & - Serologies for Lyme disease and lues & $\begin{array}{l}\text { - Serologies for HIV, toxoplasmosis, } \\
\text { bartonella hanselae, TBE/FSME, EBV, } \\
\text { hepatitis, etc. }\end{array}$ \\
\hline \multirow{3}{*}{ Immuno-logical serum screening } & Rheumatic/immunological markers & $\begin{array}{l}\text { - CRP, IgG/IgA/IgM, immune fixation } \\
\text { - CH50, C3, C4, C3d } \\
\text { - Rheumatoid factor }\end{array}$ & $\begin{array}{l}\text { - Interleukin } 6 \text {, erythrocyte } \\
\text { sedimentation rate, C1q complement } \\
\text { factor, ACE }{ }^{10} \text {, interleukin-2 receptor }{ }^{10} \text {, } \\
\text { neopterin }{ }^{10} \text {, anti-streptolysin titers }{ }^{11}, \\
\text { CCP }^{9}, \text { HLA-B51 }^{12}\end{array}$ \\
\hline & Brain-associated systemic antibodies & $\begin{array}{l}\text { - TRAKs }{ }^{13}, \text { TPO/TG }{ }^{13} \text {, and GAD } 65^{14} \\
\text { antibodies }\end{array}$ & $\begin{array}{l}\text { - Gliadin and transglutaminase } \\
\text { antibodies } 15\end{array}$ \\
\hline & $\begin{array}{l}\text { Potential antineuronal-rheumatic/other } \\
\text { rheumatic antibodies }\end{array}$ & $\begin{array}{l}\text { - ANA }{ }^{16} / \text { ANCA }^{17} \text { screening } \\
\text { - Anti-phospholipid ( }(32 \text { glycoprotein-I) } \\
\text { IgG/M antibodies }{ }^{2} \\
\text { - AMA }{ }^{18} / \text { LMA }^{19} / \text { SMA }^{19} \text { antibodies }\end{array}$ & $\begin{array}{l}\text { - Against extractable nuclear antigens } \\
\text { (ENA; ds-DNA, nRNP/Sm, Sm, SS-A/B, } \\
\text { Scl-70, nucleosomes, histones, DFS70, } \\
\text { etc.) }{ }^{16} \text {, against PR3/MPO }{ }^{17} \text {, against } \\
\text { cardiolopin }^{2}\end{array}$ \\
\hline
\end{tabular}


Table 1. Cont.

\begin{tabular}{|c|c|c|c|}
\hline & & Freiburg FDPP Screening & Additional Analyses in Selected Cases \\
\hline & $\begin{array}{l}\text { Antineuronal serum IgG } \\
\text { autoantibodies }\end{array}$ & $\begin{array}{l}\text { - Against cell surface antigens: } \\
\text { NMDA-R, AMPA-1/2-R, GABA } \\
\text { CAS, LGI1, } \\
\text { CASP2 } \\
\text { - Against intracellular antigens: Yo, Hu, } \\
\text { CV2/CRMP5, Ri, Ma1/2, SOX1, Tr, Zic4, } \\
\text { GAD65, amphiphysin } \\
\text { - Against “NMO spectrum antigens": } \\
\text { MOG, AQP4 }\end{array}$ & $\begin{array}{l}\text { - Tissue-based assays using indirect } \\
\text { immunofluorescence (IIF) on unfixed } \\
\text { murine brain tissue/neuropil antibodies } \\
\text { (IIF on fixed mouse brain tissue) } \\
\text { - Against other antineuronal antigens: } \\
\text { adenylate kinase 5, DPPX, glycine-R, } \\
\text { mGluR1/5, IgLON5, VGCC, MBP, GFAP, } \\
\text { DRD2, etc. }\end{array}$ \\
\hline \multirow{3}{*}{$\begin{array}{c}\text { Cerebro-spinal fluid basic markers and } \\
\text { antineuronal antibodies }\end{array}$} & Basic cerebrospinal fluid analyses & $\begin{array}{l}\text { - White blood cell count, total protein, } \\
\text { albumin quotient, IgG index, OCBs in } \\
\text { serum/CSF, lactate }\end{array}$ & - Glucose \\
\hline & Antineuronal IgG antibodies ${ }^{20}$ & $\begin{array}{l}\text { - Against different cell surface antigens: } \\
\text { NMDA-R, AMPA-1/2-R, GABAB-R, } \\
\text { LGI1, CASPR2 }\end{array}$ & $\begin{array}{l}\text { - Tissue-based assays using IIF on } \\
\text { unfixed murine brain tissue/neuropil } \\
\text { antibodies (IIF on fixed mouse brain } \\
\text { tissue) } \\
\text { - Against intracellular antigens: Yo, Hu, } \\
\text { CV2/CRMP5, Ri, Ma1/2, SOX1, Tr, Zic4, } \\
\text { GAD65, amphiphysin, etc. } \\
\text { - Against other antineuronal antigens: } \\
\text { adenylate kinase 5, DPPX, glycine-R, } \\
\text { mGluR1/5, IgLON5, VGCC, MBP, GFAP, } \\
\text { DRD2, etc. }\end{array}$ \\
\hline & $\begin{array}{l}\text { Infectious, neuro-degenerative and } \\
\text { other markers }\end{array}$ & & $\begin{array}{l}\text { - MRZ reaction }{ }^{21} \text {, antibody indices (AIs) } \\
\text { for HSV, Borrelia burgdorferi etc.; } \\
\text { pathogen detection of HSV, Tropheryma } \\
\text { whippelii, etc.; CXCL13 }{ }^{22} \\
\text { - Tau, p-tau }{ }^{23}, \beta \text {-amyloid quotient }{ }^{23}, \\
\text { protein } 14-3-33^{24}, \alpha \text {-synuclein }{ }^{25} \\
\text { - Cytopathology and cell markers, } \\
\text { hypocretin } 26\end{array}$ \\
\hline
\end{tabular}


Table 1. Cont.

\begin{tabular}{|c|c|c|c|}
\hline & & Freiburg FDPP Screening & Additional Analyses in Selected Cases \\
\hline \multirow{2}{*}{ Instrument-based diagnostics } & EEG & $\begin{array}{l}\text { - Resting state EEG including } \\
\text { hyperventilation period }\end{array}$ & $\begin{array}{l}\text { - Independent component analyses of } \\
\text { the EEG } \\
\text { - EEG video telemetry, sleep/sleep } \\
\text { deprivation EEG }\end{array}$ \\
\hline & Brain imaging & $\begin{array}{l}\text { - cMRI (mostly on a } 3 \text { Tesla, rarely on a } \\
1.5 \text { Tesla scanner) included T1-weighted } \\
\text { (on the } 1.5 \text { Tesla)/MPRAGE (on the } 3 \\
\text { Tesla scanner), FLAIR, and DWI } \\
\text { sequences }\end{array}$ & $\begin{array}{l}\text { - FDG-PET, TSPO-PET, SPECT } \\
\text { - Additional cMRI sequences/methods: T2*, } \\
\text { T1 + contrast agent, MR-spectroscopy; } \\
\text { resting state fMRI, DTI, etc. }\end{array}$ \\
\hline \multirow{2}{*}{ Other } & Urine & $\begin{array}{l}\text { - Urine status, urine drug screening, } \\
\text { pregnancy test (for women) }\end{array}$ & $\begin{array}{l}\text { - } \delta \text {-Amino-laevulinic }{ }^{27} \text { acid and } \\
\text { porphobilinogen concentrations }{ }^{27}\end{array}$ \\
\hline & Neuropsycho-logical testing & & - Test battery for attentional performance \\
\hline \multicolumn{4}{|c|}{ 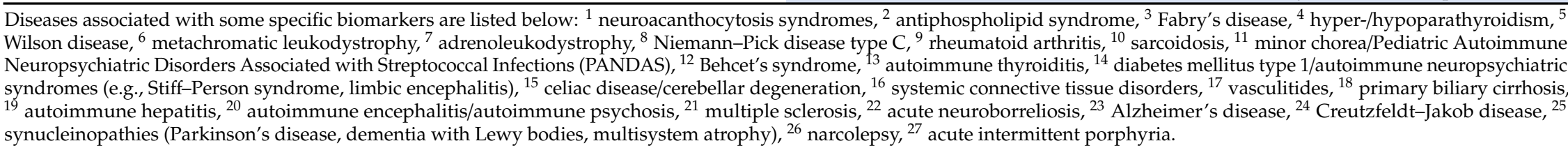 } \\
\hline
\end{tabular}




\section{Results}

\subsection{Sociodemographic Data}

Patients with SSDs were on average 37 years old and predominantly female (58\%). At the time of the initial laboratory examination, $83 \%$ of the patients with SSDs were pharmacologically treated. Table 2 gives an overview of the sociodemographic data and medication.

Table 2. Sociodemographic and psychopathological findings in patients with schizophrenia spectrum disorders (SSDs). * Following the criteria of the German "Arbeitsgemeinschaft für Methodik und Dokumentation in der Psychiatrie“ (AMDP).

\begin{tabular}{|c|c|}
\hline & Patients with SSDs $(N=76)$ \\
\hline Age in years \pm SD (range) & $37.22 \pm 14.10(19-82$ years $)$ \\
\hline Sex & 32 males/44 females \\
\hline \multicolumn{2}{|l|}{ Highest level of education } \\
\hline Low degree & $15 / 76(20 \%)$ \\
\hline Medium degree & $21 / 76(28 \%)$ \\
\hline High degree & $22 / 76(29 \%)$ \\
\hline University degree & $6 / 76(8 \%)$ \\
\hline Unknown & $12 / 76(16 \%)$ \\
\hline \multicolumn{2}{|l|}{ Present professional situation } \\
\hline Unemployed & $17 / 76(22 \%)$ \\
\hline Pension (retirement, disability) & $15 / 76(20 \%)$ \\
\hline In training/study & $17 / 76(22 \%)$ \\
\hline Unskilled/semiskilled work & $1 / 76(1 \%)$ \\
\hline Qualified/first labour market & $14 / 76(18 \%)$ \\
\hline Unknown & $12 / 76(16 \%)$ \\
\hline \multicolumn{2}{|l|}{ Abnormal psychopathological findings * } \\
\hline Attention and memory & $63 / 76(83 \%)$ \\
\hline Formal thought & $61 / 76(80 \%)$ \\
\hline Fear and compulsion & $53 / 76(70 \%)$ \\
\hline Delusions & $58 / 76(76 \%)$ \\
\hline Hallucinations & $41 / 76(54 \%)$ \\
\hline Ego-environment boundary & $32 / 76(42 \%)$ \\
\hline Affectivity & $64 / 76(84 \%)$ \\
\hline Energy and psychomotor domain & $64 / 76(84 \%)$ \\
\hline Circadian rhythm & $22 / 76(29 \%)$ \\
\hline Suicidal tendency & $14 / 76(18 \%)$ \\
\hline Global Assessment of Functioning (GAF) score & $34 \pm 15.54(N=65)$ \\
\hline \multicolumn{2}{|l|}{$\begin{array}{l}\text { Affected by disorder according to Clinical Global } \\
\text { Impression (CGI) scores }\end{array}$} \\
\hline Moderately affected & $2 / 76(3 \%)$ \\
\hline Clearly affected & $17 / 76(22 \%)$ \\
\hline Seriously affected & $39 / 76(51 \%)$ \\
\hline Extremely seriously affected & $8 / 76(11 \%)$ \\
\hline Unknown & $10 / 76(13 \%)$ \\
\hline
\end{tabular}


Table 2. Cont.

\begin{tabular}{cc}
\hline & Patients with SSDs $(\boldsymbol{N}=\mathbf{7 6})$ \\
\hline Psychopharmacological treatment & \\
\hline Atypical neuroleptics & $58(76 \%)$ \\
Typical neuroleptics & $4(5 \%)$ \\
Antidepressants & $7(9 \%)$ \\
Lithium & $8(11 \%)$ \\
Anticonvulsants (excluding benzodiazepines) & $3(4 \%)$ \\
Benzodiazepines & $7(9 \%)$ \\
Melatonin & $2(3 \%)$ \\
L-thyroxine & $8(11 \%)$ \\
\hline Overall psychopharmacological treatment & $\mathbf{6 3 ( 8 3 \% )}$ \\
\hline
\end{tabular}

\subsection{Laboratory Findings}

\subsubsection{Basic Laboratory Findings}

The following alterations in basic laboratory analyses were detected in the patients with SSDs (Table 3):

Blood count, coagulation, electrolytes: Of all patients, $14 \%$ showed increased hemoglobin value. The partial thromboplastin time (PTT) values were increased in 5\% and decreased in $9 \%$ of the patients. Calcium levels were elevated in $12 \%$ of the patients, whereas magnesium concentrations were within the normal range in all patients.

Metabolic markers: The alpha-galactosidase levels were reduced in $11 \%$ of the patients. The creatine kinase (CK) value was increased in 15\%. All except one patient with elevated liver values or elevated alkaline phosphatase received psychopharmacological treatment.

Thyroid hormones: The thyroid-stimulating hormone (TSH) values were increased in 5\%, and the free thyroxine (fT4) value was changed in $9 \%$ of the patients. The free triiodothyronine (fT3) was in the normal range in all patients. Overall, changes in thyroid hormones were observed in $12 \%$ of the patients.

Table 3. Basic laboratory analyses in patients with schizophrenia spectrum disorders (SSDs). Values with alterations in $>10 \%$ are marked in bold, parameters with changes in $>5 \%$ are written in bold and italics.

\begin{tabular}{|c|c|}
\hline & Patients with SSDs $(N=76)$ \\
\hline \multicolumn{2}{|c|}{ Differential blood count } \\
\hline Leukocytes/ $\mu \mathrm{L}($ mean $\pm \mathrm{SD})$ & $6.61 \pm 1.90$ \\
\hline Increased/decreased leukocytes (ref. $4.0-10.4 \mathrm{Tsd} / \mu \mathrm{L}$ ) & $2 \uparrow(3 \%), 4 \downarrow(5 \%), 70$ normal $(92 \%)$ \\
\hline Platelets $($ mean \pm SD) & $253.57 \pm 56.65$ \\
\hline Increased/decreased platelets (ref. 146-328 Tsd/ $\mu L$ ) & $6 \uparrow(8 \%), 1 \downarrow(1 \%), 69$ normal $(91 \%)$ \\
\hline Hemoglobin (mean \pm SD) & $14.14 \pm 1.34$ \\
\hline Increased/decreased hemoglobin (ref. 11.6-15.5 g/dL) & $11 \uparrow(14 \%), 1 \downarrow(\%), 64$ normal $(84 \%)$ \\
\hline Hematocrit (mean \pm SD) & $40.48 \pm 3.50$ \\
\hline Increased/decreased hematocrit (ref. 34.6-45.3 fL) & $5 \uparrow(7 \%), 7 \downarrow(9 \%), 64$ normal $(84 \%)$ \\
\hline Neutrophil granulocytes & $56.13 \pm 9.34$ \\
\hline $\begin{array}{l}\text { Increased/decreased neutrophil granulocyte rate } \\
\text { (ref. } 40-75 \%)\end{array}$ & $1 \uparrow(1 \%), 4 \downarrow(5 \%), 71$ normal $(93 \%)$ \\
\hline Lymphocytes (mean \pm SD) & $32.54 \pm 8.95(N=75)$ \\
\hline Increased/decreased lymphocyte rate (ref. 19-51\%) & $3 \uparrow(4 \%), 5 \downarrow(7 \%), 67$ normal $(88 \%)$ \\
\hline
\end{tabular}


Table 3. Cont.

\begin{tabular}{|c|c|}
\hline & Patients with SSDs $(N=76)$ \\
\hline \multicolumn{2}{|l|}{ Coagulation } \\
\hline Quick (mean \pm SD) & $99.06 \pm 15.71(N=72)$ \\
\hline Increased/decreased quick (ref. $70-130 \%$ ) & $0 \uparrow(0 \%), 2 \downarrow(3 \%), 70$ normal $(97 \%)$ \\
\hline INR (mean \pm SD) & $1.02 \pm 0.22(N=75)$ \\
\hline Increased/decreased INR (ref. 0.85-1.15) & $2 \uparrow(3 \%), 1 \downarrow(1 \%), 72$ normal $(96 \%)$ \\
\hline PTT (mean \pm SD) & $30.36 \pm 5.61(N=75)$ \\
\hline Increased/decreased PTT (ref. 25.1-37.7 s) & $4 \uparrow(5 \%), 7 \downarrow(9 \%), 64$ normal $(85 \%)$ \\
\hline \multicolumn{2}{|l|}{ Electrolytes } \\
\hline Sodium (mean \pm SD) & $140.68 \pm 2.00$ \\
\hline Increased/decreased sodium (ref. 136-145 mmol/L) & $1 \uparrow(1 \%), 1 \downarrow(1 \%), 74$ normal $(97 \%)$ \\
\hline Potassium $($ mean \pm SD) & $4.36 \pm 0.27$ \\
\hline Increased/decreased potassium (ref. 3.5-5.1 mmol/L) & $1 \uparrow(1 \%), 0 \downarrow(0 \%), 75$ normal $(99 \%)$ \\
\hline Calcium (mean \pm SD) & $2.39 \pm 0.16(N=75)$ \\
\hline Increased/decreased calcium (ref. $2.15-2.5 \mathrm{mmol} / \mathrm{L}$ ) & $9 \uparrow(12 \%), 1 \downarrow(1 \%), 65$ normal $(87 \%)$ \\
\hline Magnesium (mean \pm SD) & $0.85 \pm 0.06(N=72)$ \\
\hline Increased/decreased magnesium (ref. 0.66-1.07 mmol/L) & $0 \uparrow(0 \%), 0 \downarrow(0 \%), 72$ normal $(100 \%)$ \\
\hline \multicolumn{2}{|l|}{ Metabolic markers } \\
\hline Creatinine (mean $\pm \mathrm{SD})$ & $0.88 \pm 0.15$ \\
\hline Increased/decreased creatinine & $60<1(79 \%), 16<1.5(21 \%), 0 \geq 1.5(0 \%)$ \\
\hline$\alpha$-Galactosidase (mean $\pm \mathrm{SD}$ ) & $7.80 \pm 3.64(N=70)$ \\
\hline $\begin{array}{l}\text { Increased/decreased } \alpha \text {-galactosidase } \\
\text { (ref. 3.4-13 nmol/h/mL) }\end{array}$ & $7 \uparrow(10 \%), 8 \downarrow(11 \%), 55$ normal $(79 \%)$ \\
\hline $\mathrm{CK}($ mean $\pm \mathrm{SD})$ & $142.70 \pm 204.91(N=73)$ \\
\hline Increased CK (ref. < $170 \mathrm{U} / \mathrm{L}$ ) & $11 \uparrow(15 \%), 62$ normal $(85 \%)$ \\
\hline GOT $($ mean \pm SD) & $26.97 \pm 19.45$ \\
\hline Increased/decreased GOT (ref. 10-35 U/L) & $10 \uparrow(13 \%), 0 \downarrow(0 \%), 66$ normal $(87 \%)$ \\
\hline $\mathrm{GPT}($ mean $\pm \mathrm{SD})$ & $32.34 \pm 36.74$ \\
\hline Increased/decreased GPT (ref. 10-35 U/L) & $20 \uparrow(26 \%), 5 \downarrow(7 \%), 51$ normal $(67 \%)$ \\
\hline Alkaline phosphatase (mean \pm SD) & $80.13 \pm 32.69(N=70)$ \\
\hline $\begin{array}{c}\text { Increased/decreased alkaline phosphatase } \\
\text { (ref. 35-105 U/L) }\end{array}$ & $11 \uparrow(16 \%), 0 \downarrow(0 \%), 59$ normal $(84 \%)$ \\
\hline Gamma-GT (mean \pm SD) & $28.83 \pm 26.32(N=75)$ \\
\hline Increased gamma-GT (ref. $<40 \mathrm{U} / \mathrm{L}$ ) & $13 \uparrow(17 \%) 62$ normal $(83 \%)$ \\
\hline Lipase (mean \pm SD) & $32.78 \pm 12.57(N=68)$ \\
\hline Increased/decreased lipase (ref. 13-60 U/L) & $1 \uparrow(1 \%), 1 \downarrow(1 \%), 66$ normal $(97 \%)$ \\
\hline $\mathrm{HbA1C}($ mean $\pm \mathrm{SD})$ & $5.40 \pm 0.42(N=72)$ \\
\hline Increased $\mathrm{HbA} 1 \mathrm{C}$ (ref. 3.4-6\%) & $3 \uparrow(4 \%) 0 \downarrow(0 \%) 69$ normal $(96 \%)$ \\
\hline Total triglycerides (mean $\pm \mathrm{SD}$ ) & $145.23 \pm 84.05(N=70)$ \\
\hline Increased total glycerides (ref. $<150 \mathrm{mg} / \mathrm{dL}$ ) & $25 \uparrow(36 \%), 45$ normal $(64 \%)$ \\
\hline
\end{tabular}


Table 3. Cont.

\begin{tabular}{cc}
\hline & Patients with SSDs (N = 76) \\
\hline TSH (mean \pm SD) & $2.28 \pm 1.40$ \\
\hline Increased/decreased TSH (ref. 0.27-4.20 $\mathrm{UU} / \mathrm{mL})$ & $4 \uparrow(5 \%), 3 \downarrow(4 \%), 69$ normal (91\%) \\
\hline Free T3 (mean \pm SD) & $4.71 \pm 0.71$ \\
\hline Increased/decreased free T3 (ref. 3.1-6.8 pmol/L) & $0 \uparrow(0 \%), 0 \downarrow(0 \%), 76$ normal (100\%) \\
\hline Free T4 (mean \pm SD) & $16.51 \pm 3.11$ \\
\hline Increased/decreased free T4 (ref. 12-22 pmol/L) & $2 \uparrow(3 \%), 5 \downarrow(6 \%), 69$ normal (91\%) \\
\hline
\end{tabular}

\subsubsection{Vitamins/Trace Elements}

Vitamin D levels were below $20 \mathrm{ng} / \mathrm{mL}$ in $46 \%$, and below $30 \mathrm{ng} / \mathrm{mL}$ in $84 \%$; the folic acid levels were lowered in 32\%; and the vitamin B12 value was decreased in 1\% of the patients. The selenium values were reduced in $80 \%$. Overall alterations in vitamins and trace elements were detected in $92 \%$ of the patients (Table 4 ).

Table 4. Vitamins and trace elements in patients with schizophrenia spectrum disorders (SSDs). Values with alterations in $>10 \%$ are marked in bold, parameters with changes in $>5 \%$ are written in bold and italics.

\begin{tabular}{|c|c|}
\hline & Patients with SSDs $(N=76)$ \\
\hline \multicolumn{2}{|c|}{ Vitamins } \\
\hline 25-OH-Vitamin D2/D3 (mean \pm SD) & $22.16 \pm 10.71(N=74)$ \\
\hline $\begin{array}{c}\text { Increased/decreased vitamin D levels (ref. }>20 \\
\mathrm{ng} / \mathrm{mL} \text { ) }\end{array}$ & $34 \downarrow(46 \%), 40$ normal $(54 \%)$ \\
\hline Optimal vitamin D levels (ref. > 30 ng/mL) & $62 \downarrow(84 \%), 12$ optimal $(16 \%)$ \\
\hline Folic acid (mean $\pm \mathrm{SD})$ & $8.80 \pm 7.16(N=75)$ \\
\hline Increased/decreased folic acid (ref. $4.8-37.3 \mathrm{ng} / \mathrm{mL}$ ) & $0 \uparrow(0 \%), 24 \downarrow(32 \%), 51$ normal $(68 \%)$ \\
\hline Vitamin B12 (mean \pm SD) & $523.01 \pm 303.49(N=75)$ \\
\hline $\begin{array}{l}\text { Increased/decreased vitamin B12 (ref. 197-771 } \\
\text { pg/mL) }\end{array}$ & $8 \uparrow(11 \%), 1 \downarrow(1 \%), 66$ normal $(88 \%)$ \\
\hline \multicolumn{2}{|c|}{ Trace elements } \\
\hline Selenium (mean \pm SD) & $64.62 \pm 17.01(N=71)$ \\
\hline Increased/decreased selenium (ref. 75-140 $\mu \mathrm{g} / \mathrm{L}$ ) & $0 \uparrow(0 \%), 57 \downarrow(80 \%), 14$ normal $(20 \%)$ \\
\hline Vitamins and trace elements overall & 69 reduced $(92 \%), 6$ normal $(8 \%)(N=$ max. 75$)$ \\
\hline
\end{tabular}

\subsubsection{Pathogen Diagnostics}

In the Western blot, no patient showed evidence of acute Lyme disease, although 7\% displayed evidence of a previous Lyme disease infection. The lues serology was positive in one patient (1\%), however, the activity parameters and the confirmatory test were unremarkable in this patient (Table 5). Thus, there was no indication of an acute pathogen-related cause of schizophreniform symptomatology. 
Table 5. Pathogen diagnostics in patients with schizophrenia spectrum disorders (SSDs). Values with alterations in $>10 \%$ are marked in bold. * Activity parameters were negative. Lues-TPPA-positive, Lues-FTA-Abs immunoglobin (Ig)M negative, Lues-FTA-Abs IgG-positive, Lues cardiolipin agglutination-negative.

\begin{tabular}{|c|c|}
\hline & Patients with SSDs $(N=76)$ \\
\hline \multicolumn{2}{|c|}{ Serology for Lyme disease } \\
\hline IgM-ELISA screening (ref. up to 5 units) & $3 \uparrow(4 \%), 64$ normal $(89 \%), 5$ borderline $(7 \%)(N=72)$ \\
\hline IgG-ELISA screening (ref. up to $16 \mathrm{RE}$ ) & $\begin{array}{l}10 \uparrow(14 \%), 60 \text { normal }(83 \%), 2 \text { borderline }(3 \%) \\
(N=72)\end{array}$ \\
\hline $\begin{array}{l}\text { Western blot confirmation test (only performed if } \\
\text { ELISA screening was conspicuous) }\end{array}$ & $\begin{array}{l}5 \text { positive }(7 \%), 14 \text { negative }(N=19) \\
\text { - IgM: negative: } 8 \text {, positive: } 0 \\
\text { - IgG: negative: } 7 \text {, positive: } 5\end{array}$ \\
\hline \multicolumn{2}{|c|}{ Serology for lues } \\
\hline Screening using CLIA (ref. <0.9) & $1 * \uparrow(1 \%), 72 \operatorname{normal}(99 \%)(N=73)$ \\
\hline
\end{tabular}

\subsubsection{Immunological Serum Screening}

Rheumatic/immunological markers: The CRP was elevated in 17\% of the patients. Immunoglobulin (Ig)M concentrations were changed in 10\%, and the immunofixation was altered in $8 \%$. C3 was decreased in $15 \%$, and C4 was decreased in $1 \%$. C3d was elevated in $12 \%$ of the patients. The rheumatoid factor was essentially normal in all patients.

Brain-associated systemic antibodies: Anti-thyroglobulin (TG) antibodies were elevated in 4\%, and anti-thyroid peroxidase (TPO) antibodies in $12 \%$. One female patient with paranoid-hallucinatory syndrome and anti-TPO antibodies, with EEG slowing, increased albumin quotient, and cMRI atrophy responded well to steroids and was therefore re-diagnosed with Hashimoto encephalopathy (the diagnosis was already made 2017, in 2018 the symptomatology worsened again, which is why the patient was again treated as an inpatient). The anti-GAD65 antibodies measured by RIA were elevated in one patient $(1 \%)$. The anti-GAD65 antibody-positive patient suffered from catatonic schizophrenia; his EEG and cMRI showed no abnormalities, and CSF analyses only showed increased total protein. The anti-GAD65 antibodies were evaluated as non-specific in this patient.

Potential antineuronal-rheumatic and other rheumatic serum antibodies: Antinuclear antibody (ANA) reactivity was found in $15 \%$ of the patients. Extractable nuclear antigen (ENA) differentiation was clearly positive in three patients, one of these patients had anti-snRNP/Sm antibodies and the other two had anti-DFS70 antibodies. The patient with anti-snRNP/Sm antibodies was re-diagnosed with mixed connective tissue disease on the basis of the findings of discrete interstitial lung disease, Raynaud's syndrome, and probable brain involvement, as documented by abnormal EEG and FDG-PET findings. Screening for anti-neutrophil cytoplasmic antibodies (ANCAs) by indirect immunofluorescence (IIF) was positive in $3 \%$ of the patients; however, specificity against myeloperoxidase (MPO) and proteinase 3 (PR3) by ELISA testing was not found. The antiphospholipid (B2-glycoprotein-1) IgG and/or IgM antibodies were slightly elevated in $10 \%$. Non-specific white matter lesions were detected in cMRI in four of seven patients with anti-phospholipid antibodies (57\%).

Antineuronal serum IgG antibodies: Testing for the established paraneoplastic antibodies against intracellular antineuronal antigens showed clear positive antibodies against anti-Yo in one patient (1\%). This patient suffered from paranoid schizophrenia; his EEG showed intermitted generalized slow activity, his cMRI/brain FDG-PET showed no abnormalities, and CSF was not investigated (rejected by the patient). In whole body computer tomography/FDG-PET no tumor was detected. The significance of the anti-Yo antibodies remained unclear in this patient, due in part to the missing of CSF results. Six patients showed weak non-specific positive bands for Yo (three patients), SOX1 (two patients), and Zic4 (one patient; overall 8\%). All screenings for antibodies against established antineuronal cell surface antigens and anti-aquaporin 4 (AQP4) were negative in this cohort. The anti-myelin oligodendrocyte glycoprotein (MOG) antibodies were positive in one patient with atypical paranoid-hallucinatory syndrome (2\%). The EEG revealed a dysrhythmic alpha rhythm, while the 
cMRI showed non-specific white matter lesions. His CSF analyses indicated increased total protein. The anti-MOG antibody finding was repeatedly positive (also with a live cell-based assay) and was classified as of possible pathophysiological relevance, which led to the diagnosis of a potential autoimmune psychosis. For details, please see Table 6.

Table 6. Immunological findings in serum of patients with schizophrenia spectrum disorders (SSDs). Values with alterations in $>10 \%$ are marked in bold, parameters with changes in $>5 \%$ are written in bold and italics. * Abnormal findings of the immune fixation in detail: two patients with polyclonal IgA propagation, one with polyclonal IgG propagation, two with polyclonal IgM propagation, one trace evidence of a monoclonal gammopathy of the type IgG lambda.

\begin{tabular}{|c|c|}
\hline & Patients with SSDs $(N=76)$ \\
\hline \multicolumn{2}{|c|}{ Rheumatic/immunological markers } \\
\hline Increased C-reactive protein (ref. $<5 \mathrm{mg} / \mathrm{L}$ ) & $13 \uparrow(17 \%), 62$ normal $(83 \%)(N=75)$ \\
\hline IgG levels (mean \pm SD) & $10.59 \pm 1.91(N=72)$ \\
\hline IgG levels increased/decreased (ref. 7-16 g/L) & $1 \downarrow(1 \%), 1 \uparrow(1 \%), 70$ normal $(97 \%)(N=72)$ \\
\hline IgA levels (mean $\pm \mathrm{SD})$ & $2.09 \pm 0.906$ \\
\hline IgA levels increased/decreased (ref. $0.70-4 \mathrm{~g} / \mathrm{L}$ ) & $1 \downarrow(1 \%), 3 \uparrow(4 \%), 68$ normal $(94 \%)(N=72)$ \\
\hline IgM levels (mean $\pm \mathrm{SD})$ & $0.99 \pm 0.55$ \\
\hline IgM increased/decreased (ref. $0.40-2.30 \mathrm{~g} / \mathrm{L}$ ) & $4 \downarrow(6 \%), 3 \uparrow(4 \%), 65$ normal $(90 \%)(N=72)$ \\
\hline Immunofixation (screening)* & 6 altered $(8 \%) * 66$ normal $(92 \%)(N=72)$ \\
\hline CH50 (ref. 65-115\%) & $1 \downarrow(2 \%), 18 \uparrow(27 \%), 47$ normal $(71 \%)(N=66)$ \\
\hline C3 (ref. $0.90-1.80 \mathrm{~g} / \mathrm{L}$ ) & $11 \downarrow(15 \%), 0 \uparrow(0 \%), 61$ normal $(85 \%)(N=72)$ \\
\hline C4 (ref. $0.10-0.40 \mathrm{~g} / \mathrm{L}$ ) & $1 \downarrow(1 \%), 0 \uparrow(0 \%), 71$ normal $(99 \%)(N=72)$ \\
\hline Rheumatoid factor (ref. < $16 \mathrm{IE} / \mathrm{mL}$ ) & 73 normal $(100 \%)(N=73)$ \\
\hline C3d (ref. $<9 \mathrm{mg} / \mathrm{L})$ & $8 \uparrow(12 \%), 61$ normal $(88 \%)(N=69)$ \\
\hline Rheumatic markers overall & 45 positive $(60 \%), 30$ negative $(40 \%)(N=$ max. 75$)$ \\
\hline \multicolumn{2}{|c|}{ Brain-associated systemic antibodies } \\
\hline TRAKs (ref. < $1.75 \mathrm{IU} / \mathrm{L})$ & $1 \uparrow(1 \%), 72$ normal $(98 \%)(N=73)$ \\
\hline Anti-TPO antibodies (ref. $<34 \mathrm{IU} / \mathrm{mL}$ ) & $9 \uparrow(12 \%), 66$ normal $(88 \%)(N=75)$ \\
\hline Anti-TG antibodies (ref. < $115 \mathrm{IU} / \mathrm{mL}$ ) & $3 \uparrow(4 \%), 71$ normal $(96 \%)(N=74)$ \\
\hline Anti- GAD65 antibodies measured by RIA & $1 \uparrow(1 \%), 1$ borderline $(1 \%), 68$ normal $(97 \%)(N=70)$ \\
\hline Anti-thyroid and diabetes antibodies overall & 12 positive $(16 \%), 63$ negative $(84 \%)(N=$ max. 75$)$ \\
\hline \multicolumn{2}{|c|}{ Potential antineuronal-rheumatic and other rheumatic serum antibodies } \\
\hline $\begin{array}{c}\text { Anti-phospholipid//32GP IgG antibodies } \\
\text { (ref. }<14 \text { GPL-U/mL) }\end{array}$ & $\begin{array}{c}5 \uparrow(7 \%), 68 \text { normal }(93 \%)(N=73)(\text { range from } 15 \text { to } \\
19 \text { GPL-U/mL) }\end{array}$ \\
\hline $\begin{array}{l}\text { Anti-phospholipid/B2GP IgM antibodies } \\
\text { (ref. }<10 \text { MPL-U/mL) }\end{array}$ & $\begin{array}{l}3 \uparrow(4 \%), 69 \text { normal }(96 \%)(N=72) \\
\text { (range from } 1 \text { to } 32 \text { MPL-U/mL) }\end{array}$ \\
\hline ANA-Hep-2 (against nucleus) & $\begin{array}{l}\text { Positive } 9(\mathbf{1 2} \%) \text {, negative } 65(88 \%)(N=74)(\text { In } \\
\text { detail: trace finely spotted: } 2 ;(+) \text { spotted: } 1+; \text { spotted: } 1 \text {; } \\
\text { trace homogeneous: } 2 ;(+)-+ \text { homogeneous: } 1 ;(+) \\
\text { homogeneous: } 1 ;+ \text { homogeneous-fine-spotted: } 1)\end{array}$ \\
\hline ANA-Hep-2 (nucleoli) & Positive $0(0 \%)$, negative $74(100 \%)(N=74)$ \\
\hline ANA-Hep-2 (chromosomes) & $\begin{array}{l}\text { Positive } 4(5 \%) \text {, negative } 70(95 \%)(N=74) \\
\text { (In detail: trace: } 1,(+): 1,+ \text { stripy: } 1,(+)-+ \\
\text { homogeneously: } 1)\end{array}$ \\
\hline ANA-Hep-2 (cytoplasm) & $\begin{array}{c}\text { Positive } 2(3 \%), \text { negative } 72(97 \%) \\
(N=74) \text { (In detail: Trace reticular: } 2)\end{array}$ \\
\hline
\end{tabular}


Table 6. Cont.

\begin{tabular}{|c|c|}
\hline & Patients with SSDs $(N=76)$ \\
\hline ANA overall positive/borderline findings & Positive $11(15 \%)$, negative $63(85 \%)(N=$ max. 74$)$ \\
\hline $\begin{array}{l}\text { ENA screening (only performed if ANAs were } \\
\text { clearly positive) }\end{array}$ & $\begin{array}{c}\text { Positive } 3(33 \%) \text {, negative } 6(66 \%) \\
(N=9) \\
\text { Positive cases in detail: anti-snRNP/Sm }+++ \text { in one } \\
\text { patient, anti-DFS70 +++ in two patients; anti-centromere } \\
(C E N P \text { B })(+) \text { in one patient, anti-AMA-M2 }(\operatorname{Ig} G)(+) \text { in } \\
\text { one patient }\end{array}$ \\
\hline $\begin{array}{l}\text { Anti-dsDNA ELISA (ref. }<40 \mathrm{U} / \mathrm{mL} \text {; only performed } \\
\text { if ANAs were clearly positive and suspicious clinical } \\
\text { findings were present) }\end{array}$ & $\begin{array}{c}12.33 \pm 7.02(N=3) \\
0 \uparrow(0 \%), 3 \text { normal }(100 \%)\end{array}$ \\
\hline ANCAs (IgG, ref. 1:10) & $\begin{array}{c}2 \text { positive }(3 \%), 71 \text { negative }(97 \%)(N=73) \\
\text { Positive cases: } n=1 \text { anti-MPO negative }(2 \mathrm{U} / \mathrm{mL} ; \text { ref. }<5 \\
\mathrm{U} / \mathrm{mL}), \text { anti-PR3 negative }(1 \mathrm{U} / \mathrm{mL} ; \text { ref. }<10 \mathrm{U} / \mathrm{mL} ; \\
\text { in } n=1 \text { not performed }\end{array}$ \\
\hline AMA/LKM (kidney, ref. 1:50) & 0 Positive $(0 \%), 60$ negative $(100 \%)(N=60)$ \\
\hline SMA (kidney, ref. 1:50) & $\begin{array}{c}4 \text { borderline positive }(7 \%), 56 \text { negative }(93 \%)(N=60) \\
\text { (In detail: } n=2 \text { trace, } n=2(+))\end{array}$ \\
\hline Rheumatic antibodies overall & 23 positive $(31 \%), 51$ negative $(69 \%)(N=\max .74)$ \\
\hline \multicolumn{2}{|l|}{ Established antineuronal serum antibodies } \\
\hline $\begin{array}{c}\text { Antibodies against intracellular onconeural antigens } \\
\left(H u, Y_{0}, R i, c v 2(C R M P 5), M a 1 /-M a 2, S O X, \operatorname{Tr}(D N E R),\right. \\
\text { Zic4, amphiphysin, GAD65) }\end{array}$ & $\begin{array}{l}\text { Clear positive: in } 1 \text { case }\left(Y_{0} ; 2 \%\right) \\
\text { Weak, non-specific bands: in } 5 \text { cases (Yo 3x, SOX 2x, } \\
\text { Zic4 1x; } 8 \%) \\
\text { Negative: } 54(90 \%)(N=60)\end{array}$ \\
\hline $\begin{array}{l}\text { Antibodies against neuronal cell surface antigens } \\
(L G I 1, C A S P R 2, G A B A-B, N M D A-R, A M P A 1 / 2)\end{array}$ & 0 positive $(0 \%), 56$ negative $(100 \%)(N=56)$ \\
\hline Anti-AQGP4 antibodies & 0 positive $(0 \%), 52$ negative $(100 \%)(N=52)$ \\
\hline Anti-MOG antibodies & 1 positive $(2 \%), 49$ negative $(98 \%)(N=50)$ \\
\hline
\end{tabular}

\subsection{Cerebrospinal Fluid Findings}

CSF analyses were performed in 48 of 76 patients, corresponding to a rate of $63 \%$. Two of the patients without CSF results received a lumbar puncture in the course of the disease. Therefore, a total of $66 \%$ of the patients agreed to lumbar puncture. The CSF WBC count was not increased in the included sample. One increased WBC count was caused by blood admixture, the corrected value was normal (correction formula: 1 cell/ $\mu \mathrm{L}$ of $\mathrm{WBC}$ count reduction per 1000 red blood cells $/ \mu \mathrm{L}$ ). The total protein was elevated in $56 \%$ of the patients. The albumin quotients were increased in $21 \%$. The IgG index was increased in $4 \%$, and oligoclonal bands (OCBs) in the CSF were found in one patient $(2 \%)$. In $45 \%$ of the patients, the lactate levels were below the lower reference value. None of the patients displayed antineuronal antibodies against the established antigens in the CSF. Overall, CSF alterations (without reduced lactate) were detected in $54 \%$ of the patients (for details, see Table 7). 
Table 7. Cerebrospinal fluid findings in patients with schizophrenia spectrum disorders (SSDs). Values with alterations in $>10 \%$ are marked in bold, parameters with changes in $>5 \%$ are written in bold and italics.

\begin{tabular}{|c|c|}
\hline & Patients with SSDs $(N=48)$ \\
\hline \multicolumn{2}{|l|}{ CSF basic analyses } \\
\hline WBC count (mean \pm SD) & $1.38 \pm 0.67$ \\
\hline Increased WBC count (ref. $<5 / \mu \mathrm{L})$ & $0 \uparrow(0 \%), 48$ normal $(100 \%)$ \\
\hline Protein $($ mean \pm SD) & $553.18 \pm 401.82(N=45)$ \\
\hline Increased protein (ref. $<450 \mathrm{mg} / \mathrm{L}$ ) & $25 \uparrow(56 \%), 20$ normal $(44 \%)$ \\
\hline Albumin quotient (mean \pm SD) & $6.14 \pm 5.39$ \\
\hline $\begin{array}{l}\text { Increased albumin quotient (references: }<40 \text { years: } \\
\begin{array}{c}<6.5 \times 10^{-3} ; 40-60 \text { years: }<8 \times 10^{-3} ;>60 \text { years: } \\
\left.<9.3 \times 10^{-3}\right)\end{array}\end{array}$ & $10 \uparrow(21 \%), 38$ normal $(79 \%)$ \\
\hline $\operatorname{IgG}$ index $($ mean $\pm \mathrm{SD})$ & $0.52 \pm 0.09$ \\
\hline $\begin{array}{c}\text { Number of patients with increased IgG indices } \\
\text { (ref. }<0.7 \mathrm{mg} / \mathrm{L})\end{array}$ & $2 \uparrow(4 \%), 46$ normal $(96 \%)$ \\
\hline Oligoclonal bands in CSF & 47 negative $(98 \%), 1$ positive $(2 \%)$ \\
\hline Oligoclonal bands in serum & 48 negative $(100 \%), 0$ positive $(0 \%)$ \\
\hline Lactate $($ mean $\pm \mathrm{SD})$ & $1.60 \pm 0.29(N=40)$ \\
\hline $\begin{array}{l}\text { Increased lactate (ref. } 16-50 \text { years: } 1.5-2.1 \mathrm{mmol} / \mathrm{L} ; \\
\qquad>51 \text { years } 1.7-2.6 \mathrm{mmol} / \mathrm{L})\end{array}$ & $18 \downarrow(45 \%), 0 \uparrow(0 \%), 22$ normal $(55 \%)$ \\
\hline $\begin{array}{l}\text { CSF overall alterations (without decreased } \\
\text { lactate levels) }\end{array}$ & $26 / 48(54 \%)$ \\
\hline \multicolumn{2}{|l|}{ Established antineuronal antibodies } \\
\hline $\begin{array}{c}\text { Antibodies against established cell surface antigens } \\
\text { (LGI1, CASPR2, GABA B, NMDA, AMPA } 1 \text { and AMPA } \\
\text { 2, DPPX) }\end{array}$ & 47 negative $(100 \%), 0$ positive $(0 \%)(N=47)$ \\
\hline
\end{tabular}

\subsection{Instrument-Based Diagnostics}

The EEGs indicated alterations in $29 \%$ of the patients, most frequently with intermittent generalized slow activity (IRDAs/IRTAs). In the cMRI, alterations were found in $61 \%$ of the patients, most frequently with non-specific white matter lesions (in 38\%; if each singular lesion was assessed as altered). Pineal cysts were detected in $16 \%$ and chronic inflammatory lesions in $4 \%$. For details, please see Table 8.

Table 8. Electroencephalography (EEG) and cerebral magnetic resonance imaging (cMRI) alterations in patients with schizophrenia spectrum disorders (SSDs). * Two patients had white matter lesions compatible with chronic inflammatory changes. One patient had multiple sclerosis-typical MRI lesions. This patient suffered from an isolated psychotic episode. She was diagnosed with multiple sclerosis in the past; however, the patient was not given prophylaxis against relapse. ${ }^{* *}$ Two patients were only suspected of having a pineal cyst. Abbreviation: IRDA/IRTA, intermittent generalized rhythmic delta/theta activity; HV, hyperventilation.

\begin{tabular}{cc}
\hline \multicolumn{2}{c}{ EEG $(\boldsymbol{N}=\mathbf{7 6})$-Visual assessment } \\
\hline \multicolumn{2}{c}{ Patients with SSDs } \\
\hline Continuous generalized slow activity & $0 / 76(0 \%)$ \\
Continuous regional slow activity & $1 / 76(1 \%)$ \\
Intermittent generalized slow activity & $16 / 76(21 \%)$ \\
Intermittent regional slow activity & $6 / 76(8 \%)$ \\
Epileptic pattern & $0 / 76(0 \%)$ \\
EEG overall alterations & $\mathbf{2 2 / 7 6 ( 2 9 \% )}$ \\
\hline
\end{tabular}


Table 8. Cont.

\begin{tabular}{cc}
\hline & Patients with SSDs \\
\hline EEG $(\boldsymbol{N}=\mathbf{7 6})$-Automatic IRDA/IRTA quantification (mean values) \\
\hline IRDA/IRTA rate before hyperventilation & $1.18 \pm 1.79(\mathrm{~N}=76)$ \\
IRDA/IRTA rate after hyperventilation & $1.64 \pm 2.23(N=66$, hyperventilation was \\
not performed in all patients) \\
IRDA/IRTA difference & $0.46 \pm 1.59(\mathrm{~N}=66)$ \\
(post-hyperventilation-pre-hyperventilation) & $\mathbf{1 . 2 7} \pm \mathbf{1 . 7 0}(\mathbf{N = \mathbf { 7 6 } )}$ \\
IRDA/IRTA rates overall & \\
\hline cMRI $(\boldsymbol{N}=\mathbf{7 4})$-Visual assessment \\
\hline (Non-specific) white matter lesions & $28 / 74(38 \%)$ \\
Chronic inflammatory lesions * & $3 / 74(4 \%)$ \\
Atrophy & $1 / 74(1 \%)$ \\
Pineal cyst ** & $12 / 74(16 \%)$ \\
Others & $19 / 74(26 \%)$ \\
cMRI overall alterations & $\mathbf{4 5 / 7 4 ( 6 1 \% )}$
\end{tabular}

\subsection{Overall Alterations}

Immunological blood alterations were detected in $76 \%$ of the patients. Vitamin and trace element deficiency was detected in $92 \%$. Overall CSF alterations (without decreased lactate) were found in $54 \%$ of the patients. The combination of EEG, cMRI, and CSF analysis resulted in alterations in $76 \%$ of the patients. Autoimmune psychosis was suspected in three patients $(4 \%$; one with Hashimoto encephalopathy, one with anti-MOG antibody-associated psychosis, and one with mixed connective tissue disease with probable brain involvement). Another patient, who was not included in this analysis because he was under 18 years of age in 2018 (exclusion criterion), had an autoimmune psychosis with novel antineuronal antibodies in the tissue test.

\subsection{Correlation Analyses}

CSF WBC count correlated significantly with IRDAs per minute $(r=0.336, p=0.019)$, with IRDAs per minute before hyperventilation $(r=0.399, p=0.005)$ and with IRDAs per minute after hyperventilation $(r=0.333, p=0.029)$. Other than that, there were no significant correlations between CSF markers and IRDA/IRTA rates.

\section{Discussion}

In this paper, we present the Freiburg Diagnostic Protocol in Psychosis (FDPP) and show that it could produce relevant findings in a substantial subgroup of patients with SSDs. Applying FDPP screening, autoimmune psychosis was suspected in $4 \%$ and immunological blood alterations were detected in $76 \%$ of patients with SSDs. The combination of EEGs, cMRIs, and CSF also resulted in alterations in $76 \%$ of the patients. Modulating factors for the course of the disease (neurovitamins and trace elements) revealed levels below the recommended reference values in $92 \%$ of all patients. On the basis of these findings, we feel that such an extended screening approach in patients with SSDs could be worthwhile. Anticipating criticisms, as the majority of findings might not be clinically relevant, we want to discuss the significance of these alterations, but also possible limitations, for the detection of SSSDs and specific treatment below.

\subsection{Blood Analyses}

Surprisingly, the basic laboratory findings showed signs of hypercalcemia in $12 \%$ of the patients. These findings could indicate endocrinological disorders (e.g., primary hyperparathyroidism, hyperthyroidism, or adrenal cortex hypofunction), malignant tumors (e.g., plasmocytoma, paraneoplastic processes), or sarcoidosis [20], but also can occur due to lack of exercise. There were reduced levels of $\alpha$-galactosidase in 11\%; this could indicate Fabry's disease, an X-linked recessive 
lipid storage disease characterized by $\alpha$-galactosidase deficiency, which could be confirmed with a mutation analysis. The association between Fabry's disease and depression is known, and an association with psychoses has been discussed [21,22]. Given these findings, the question arises whether there might be minor variants of metabolic diseases such as Fabry's disease that could be of causal relevance in the development of mental disorders. This hypothesis cannot be answered presently since there is still too little research done in this area. In our patients and on the basis of present knowledge, we made the clinical judgment that they did not suffer from full blown Fabry's disease because the currently accepted critical symptoms were not present (strokes, polyneuropathies, angiokeratomas, renal insufficiency; [23]); however, we recommended that patients undergo genetic testing. Alternatively, alpha-galactosidase deficiency could have been induced by antipsychotics. The frequently increased transaminases (GOT in 13\%, GPT in 26\%), $\gamma$-GT (in 17\%), and alkaline phosphatase (in 16\%) were most likely due to psychotropic drugs.

Vitamin and trace element analyses revealed deficiencies in $92 \%$ of the patients. Suboptimal vitamin D levels were detected in $84 \%$, and reduced folic acid concentrations were present in $32 \%$. Vitamin D seems to have both immunomodulatory effects, via its effect on $\mathrm{T}$ and B lymphocytes, and neuroprotectant and neurotrophic effects [24]; therefore, substitution therapy is recommended in patients with multiple sclerosis and rheumatic diseases. The significance of vitamin D deficiency for SSDs is currently the subject of intense discussion [25]. In patients with deficiency, we offered substitution of vitamin D. Folic acid is responsible for cell division and cell maintenance [26], and a deficiency can lead to leukoencephalopathy with psychiatric symptoms [27]. In patients with SSDs, a substitution with folic acid might be useful in reducing negative symptoms [28]. In patients with deficiency, we suggested substitution of folic acid. Selenium levels were below the recommended limits in $80 \%$ of the patients, which is in line with the findings of a previous study on schizophrenia [29]. Selenium deficiency appears to be associated with an increased risk of autoimmune thyroiditis; selenium can reduce thyroid antibody levels and may exert its immunomodulatory effects by reducing pro-inflammatory cytokines [30]. In patients with deficiency, we offered substitution of selenium. The vitamin or selenium deficiency states could not only be causally involved in the development of the schizophreniform symptoms, but could also be secondary (e.g., a vitamin D deficiency could be caused by avoiding sunlight through social withdrawal).

The most common anti-thyroid antibodies were directed against TPO, which were elevated in $12 \%$ of the patients. These antibodies may indicate autoimmune thyroiditis, but, after exclusion of antineuronal autoantibodies, they might, in rare cases, also be associated with Hashimoto encephalopathy in patients with unclear cases of autoimmune encephalitis $[9,10]$, as was probably the case with one patient of the present cohort. Low levels of positive anti-GAD56 antibodies are found in diabetes mellitus, however, in our cohort, one patient had increased concentrations of anti-GAD65 antibodies in RIA without diabetes mellitus. Increased levels of anti-GAD65 antibodies are found more frequently in patients with psychosis than in control groups [31] and can be associated with limbic encephalitis in a subgroup of the patients with high titers; however, their pathophysiological role is not yet clear [32]. The rheumatic screening showed CRP increases in 17\% of the patients. Slightly elevated CRP levels have been described on a meta-analytical level, and elevated CRP values support the idea of systemic low-grade inflammation in a subgroup of the patients with SSDs [33]. Complement factor analysis showed frequently decreased levels of C3 (15\%). Lowered C3 concentrations are classically found in patients with immune complex diseases, such as systematic lupus erythematosus [34], which in turn can mimic psychoses [35]. As one molecular genetic investigation in schizophrenia identified a complement factor $\mathrm{C} 4$ gene variant as a potential genetic marker [36], there may be a direct association between schizophrenia and the complement system.

The rheumatoid factor was normal in all patients. This finding is compatible with the results of large studies, which show a negative correlation between SSD and rheumatoid arthritis. The underlying pathophysiological processes are not conclusively clarified [37] but could possibly be caused by aberrant inflammatory cytokine profiles [38]. Anti-phospholipid antibodies were slightly increased in 10\% of 
the patients. The presence of anti-phospholipid antibodies in some patients with schizophrenia is known [39], and SSD may also occur in patients with fully developed anti-phospholipid syndrome [40]. Conspicuous ANAs were found in $15 \%$ of the patients. Other studies showed comparable findings (e.g., [41]); these "potentially antineuronal" antibodies may be a sign of connective tissue diseases. Clear evidence of connective tissue diseases was found in extractable nuclear antigen (ENA) testing, with anti-snRNP/Sm specificity in one patient, who was subsequently re-diagnosed with mixed connective tissue disease with suspected brain involvement. In two patients, anti-DFS70 antibodies were found, indicating the absence of ANA-associated rheumatic diseases [42]. In addition to one patient with anti-GAD65 antibodies in the RIA, there were two other cases where testing clearly revealed positive results for antineuronal serum antibodies. One patient with schizophreniform syndrome had anti-Yo antibodies in the serum, while the additional findings revealed no clear signs for brain involvement. Another patient with atypical psychosis, as well as EEG and cMRI alterations, was tested positive for anti-MOG antibodies. In the context of the presently expanding spectrum of neuromyelitis optica (NMO) spectrum disorders [43], we suspected a potential autoimmune psychosis.

\subsection{CSF Markers}

Overall, $66 \%$ of patients agreed to a lumbar puncture. The patients were only examined after their written informed consent, and no emergency LPs were performed against the will of the patients. This shows relatively high acceptance of this procedure on our specialized ward and demonstrates that lumbar punctures can be successfully performed in a psychiatric setting. The CSF findings showed evidence of inflammatory changes in $4 \%$ (increased IgG indices in two patients, with OCBs in one patient), while a blood-brain barrier dysfunction with increased albumin quotients was observed in $21 \%$ (elevated CSF protein levels have even been reported in $>50 \%$ of patients, but on the basis of current knowledge they are no longer suggested as optimal markers of blood-brain barrier dysfunction, and albumin ratios should be preferred as they better reflect the underlying decreased CSF flow rate; [44,45]). WBC counts correlated with IRDA/IRDA rates in EEGs. While inflammatory change frequency was lower than in previous studies, the frequency of disturbed blood-brain barrier parameters was previously described with similar figures [14,46,47]. The blood-brain dysfunction's role in the pathophysiology of schizophreniform psychosis is currently under intense discussion (see $[48,49])$. The established antineuronal IgG antibodies against cell surface antigens were negative in the patients studied here, which aligns with the findings of Oviedo-Salcedo and colleagues (2018), using the same methodology [50]. However, in 2018, no screening using tissue-based assays using indirect immunofluorescence screening on brain sections of rodents were performed on our ward. It was not until the end of 2018 that we started to do this and, in the meantime, detected some pathological findings that led to the diagnosis of possible autoimmune psychosis (e.g., [12,13]) in patients in whom the overall clinical judgment would sometimes not have led to this diagnosis without this finding. Novel autoantibodies against still-unknown antigens, which we unfortunately did not investigate here, may play a more important role than established antineuronal antibodies against cell surface antigens in psychiatric diseases.

\subsection{Instrument-Based Diagnostics}

EEG alterations were detected in $29 \%$ of the patients, and (mostly non-specific) cMRI alterations in $61 \%$. IRDAs/IRTAs were the most frequently detected alterations using EEG (in 21\%). Earlier studies showed similar findings [14,51]. These EEG alterations may be an indication of neuronal network instability (see local area network inhibition hypothesis; [52]). Clinically they might be a finding that supports the consideration of anticonvulsive therapy trials [52]. The most common cMRI alteration was the presence of non-specific white matter changes (in 38\%) when evaluating each small lesion. However, only in $4 \%$ of patients were chronic inflammatory lesions detected. White matter lesions may be associated with neuroinflammatory processes [53], but non-specific changes can often also be found in healthy controls [54]. Pineal cysts were found in $16 \%$ of the patients; these findings were 
usually interpreted as non-specific. However, the prevalence in our cohort seems to be much higher than in controls. For example, in one imaging study of 1400 healthy control subjects, the prevalence was only $2 \%$ [55]. The significance of pineal cyst findings in patients with SSDs is unclear. One case report describing an improvement of psychotic symptoms after resection of a pineal epidermoid cyst in a 23-year-old male patient [56] indicates that such incidental findings might be of clinical relevance at least in some patients. Thus, whether there is a pathophysiological association between pineal cysts and psychosis should be investigated in future studies.

\subsection{Overall Alterations}

Earlier studies have described a clear bidirectional association between autoimmune diseases and SSDs [57-59]. In this study, slight immunological alterations were found in the serum of $76 \%$ of the patients. The combination of EEG, cMRI, and CSF also showed abnormalities in $76 \%$ of the patients. In some cases, this led to the clear diagnosis and treatment of a concomitant disorder (e.g., in a patient with anti-snRNP/Sm antibodies who was diagnosed with mixed connective tissue disease). In other cases, the significance of more singular findings such as only EEG slowing, cMRI white-matter lesions, or CSF abnormalities remained unclear. This common clinical constellation with only one pathological but still non-specific abnormal finding is difficult to interpret for the clinician and clearly warrants more intensive clinical research in this area, whereas frequent deficiencies of vitamins and selenium can be substituted.

\subsection{Limitations}

The results are limited by the uncontrolled, open, and retrospective design. Due to the uncontrolled design, no comparison with a healthy or psychiatric control group was possible, although laboratory and CSF values were compared to established reference values. However, therefore it cannot be clarified whether the current findings are disease-specific results for patients with schizophreniform disorders. Due to the open and retrospective design, many findings were not available for the entire patient sample. The open and university setting and the relatively small sample size also may have led to a distortion (selection bias) of the results. The screening suggested here was based on our own clinical experiences and was adapted over the last few years. For example, the MRZ reaction was also recorded temporarily, but this did not have relevant clinical consequences and was not further investigated in the course of the screening [60]. Further blood markers (e.g., ceruloplasmin, broader pathogen search, genetic testing) or additional investigations (e.g., FDG-PET) could be useful in some patients (see Table 1). With regard to the analysis of antineuronal antibodies against cell surface antigens in serum and CSF, which were completely negative in the presented patient group, more sensitive methods (live cell-based assays and tissue-based assays using indirect immunofluorescence on fixed/unfixed murine brain tissue) could be of higher clinical benefit $[12,13,61]$.

\section{Conclusions}

In this paper, the authors presented the concept of the FDPP screening, a comprehensive, multimodal diagnostic screening approach that includes broad laboratory testing in blood and CSF, as well as cMRI and EEG investigations, designed to exclude secondary, organic causes in patients with SSDs. Lumbar punctures were performed in well over half the cases. Thus, our data show that implementation of lumbar punctures in a psychiatric setting is possible. In contrast to the recommendations of most international guidelines, FDPP screening includes comprehensive diagnostic screening measures that generally are only sought in cases with clear clinical evidence of such secondary disorders. On the basis of our clinical experience that secondary variants of psychotic disorders may present like primary, idiopathic SSDs $[12,13,15]$, we developed the FDPP approach at our center in recent years. The study shows that a broad organic assessment in patients with psychosis could be helpful in detecting secondary, organic psychoses. Our study indicates that with the FDPP approach, autoimmune psychosis can be found in about $4 \%$ of patients and that alterations in modulating factors 
such as neurovitamins and trace element alterations are found in about $92 \%$. The interpretation of other non-specific findings (e.g., isolated weakly elevated anti-phospholipid antibodies, isolated IRDAs/IRTAs in EEG) requires further research. Larger and controlled studies in the future could help refine this multimodal screening approach in an effort to identify and differentially treat patients with primary idiopathic presentation of what then turns out to be SSSD. On the basis of our clinical experience, most patients and relatives welcome this approach, even in the case of negative or unclear findings. With respect to this approach's costs, we feel that this is not relevant, given the severity of the diseases in question and the far-reaching psychosocial and occupational consequences that a faulty diagnosis of primary, idiopathic SSD might hold.

Author Contributions: D.E. and L.T.v.E. established the screening approach. M.M. (Miriam Matysik) prepared the results section (under the supervision of D.E. and L.T.v.E.), she was supported from S.M. D.E. wrote the paper. B.F. performed and interpreted the automated EEG analyses. N.V. performed and interpreted the rheumatic analyses. K.R., S.J.M., K.N., T.S., M.M. (Miriam Matysik), M.M. (Maike Michel), K.B., K.D., and L.T.v.E. supported the clinical interpretation. H.U. was responsible for MRI analyses and interpretation. All authors were critically involved in the theoretical discussion and composition of the manuscript. All authors read and approved the final version of the manuscript.

Funding: The article processing charge was funded by the Baden-Wuerttemberg Ministry of Science, Research and Art and the University of Freiburg in the funding program Open Access Publishing.

Acknowledgments: D.E. was funded by the Berta-Ottenstein-Programme for Advanced Clinician Scientists, Faculty of Medicine, University of Freiburg.

Conflicts of Interest: D.E.: none. M.M. (Miriam Matysik): none. B.F.: none. N.V.: none. T.S.: none. M.M. (Maike Michel): none. S.M.: none. K.R.: none. S.J.M.: none. K.N.: none. K.B.: none. H.U.: shareholder of the Veobrain GmbH. K.D.: Steering Committee Neurosciences, Janssen. L.T.vE.: advisory boards, lectures, or travel grants within the last three years: Roche, Eli Lilly, Janssen-Cilag, Novartis, Shire, UCB, GSK, Servier, Janssen, and Cyberonics.

\section{References}

1. Marder, S.R.; Cannon, T.D. Schizophrenia. N. Engl. J. Med. 2019, 381, 1753-1761. [CrossRef]

2. Owen, M.J.; Sawa, A.; Mortensen, P.B. Schizophrenia. Lancet 2016, 388, 86-97. [CrossRef]

3. Serafini, G.; Pompili, M.; Haghighat, R.; Pucci, D.; Pastina, M.; Lester, D.; Angeletti, G.; Tatarelli, R.; Girardi, P. Stigmatization of schizophrenia as perceived by nurses, medical doctors, medical students and patients. J. Psychiatry Ment. Health Nurs. 2011, 18, 576-585. [CrossRef]

4. Fusar-Poli, P.; Smieskova, R.; Serafini, G.; Politi, P.; Borgwardt, S. Neuroanatomical markers of genetic liability to psychosis and first episode psychosis: A voxelwise meta-analytical comparison. World J. Biol. Psychiatry 2014, 15, 219-228. [CrossRef]

5. Tebartz van Elst, L. Vom Anfang und Ende der Schizophrenie: Eine Neuropsychiatrische Perspektive auf das Schizophrenie-Konzept; Kohlhammer: Stuttgart, Germany, 2017.

6. Keshavan, M.S.; Kaneko, Y. Secondary psychoses: An update. World Psychiatry 2013, 12, 4-15. [CrossRef]

7. Pollak, T.A.; Lennox, B.R.; Müller, S.; Benros, M.E.; Prüss, H.; Tebartz van Elst, L.; Klein, H.; Steiner, J.; Frodl, T.; Bogerts, B.; et al. Autoimmune psychosis: An international consensus on an approach to the diagnosis and management of psychosis of suspected autoimmune origin. Lancet Psychiatry 2020, 7, 93-108. [CrossRef]

8. DGPPN e.V. (Hrsg.) für die Leitliniengruppe: S3-Leitlinie Schizophrenie. Langfassung, 2019, Version 1.0, Zuletzt Geändert am 15. März 2019. Available online: https://www.awmf.org/leitlinien/detail/1//038-009.html (accessed on 5 September 2020).

9. Endres, D.; Bechter, K.; Prüss, H.; Hasan, A.; Steiner, J.; Leypoldt, F.; Tebartz van Elst, L. Autoantibody-associated schizophreniform psychoses: Clinical symptomatology. Nervenarzt 2019, 90, 547-563. [CrossRef]

10. Graus, F.; Titulaer, M.J.; Balu, R.; Benseler, S.; Bien, C.G.; Cellucci, T.; Cortese, I.; Dale, R.C.; Gelfand, J.M.; Geschwind, M.; et al. A clinical approach to diagnosis of autoimmune encephalitis. Lancet Neurol. 2016, 15, 391-404. [CrossRef] 
11. Tebartz van Elst, L.; Bechter, K.; Prüss, H.; Hasan, A.; Steiner, J.H.; Leypoldt, F.; Endres, D. Autoantibody-associated schizophreniform psychoses: Pathophysiology, diagnostics, and treatment. Nervenarzt 2019, 90, 745-761. [CrossRef]

12. Endres, D.; Prüss, H.; Rauer, S.; Süß, P.; Venhoff, N.; Feige, B.; Schweizer, T.; Nickel, K.; Maier, S.; Egger, K.; et al. Probable autoimmune catatonia with antibodies against cilia on hippocampal granule cells and highly suspicious cerebral FDG-PET findings. Biol. Psychiatry 2020, 87, e29-e31. [CrossRef]

13. Endres, D.; Rauer, S.; Pschibul, A.; Süß, P.; Venhoff, N.; Runge, K.; Feige, B.; Denzel, D.; Nickel, K.; Schweizer, T.; et al. Novel antineuronal autoantibodies with somatodendritic staining pattern in a patient with autoimmune psychosis. Front. Psychiatry 2020, 11, 627. [CrossRef] [PubMed]

14. Endres, D.; Perlov, E.; Baumgartner, A.; Hottenrott, T.; Dersch, R.; Stich, O.; Tebartz van Elst, L. Immunological findings in psychotic syndromes: A tertiary care hospital's CSF sample of 180 patients. Front. Hum. Neurosci. 2015, 9, 476. [CrossRef] [PubMed]

15. Tebartz van Elst, L.; Klöppel, S.; Rauer, S. Voltage-gated potassium channel/LGI1 antibody-associated encephalopathy may cause brief psychotic disorder. J. Clin. Psychiatry 2011, 72, 722-723. [CrossRef] [PubMed]

16. Engelborghs, S.; Niemantsverdriet, E.; Struyfs, H.; Blennow, K.; Brouns, R.; Comabella, M.; Dujmovic, I.; van der Flier, W.; Frölich, L.; Galimberti, D.; et al. Consensus guidelines for lumbar puncture in patients with neurological diseases. Alzheimers Dement. 2017, 8, 111-126. [CrossRef]

17. Venhoff, N.; Thiel, J.; Rizzi, M.; Venhoff, A.; Rauer, S.; Endres, D.; Hentze, C.; Staniek, J.; Huzly, D.; Voll, R.E.; et al. The MRZ-reaction and specific autoantibody detection for differentiation of ANA-positive multiple sclerosis from rheumatic diseases with cerebral involvement. Front. Immunol. 2019, 10, 514. [CrossRef]

18. Endres, D.; Maier, S.; Feige, B.; Mokhtar, N.B.; Nickel, K.; Goll, P.; Meyer, S.A.; Matthies, S.; Ebert, D.; Philipsen, A.; et al. Increased rates of intermittent rhythmic delta and theta activity in the electroencephalographies of adult patients with attention-deficit hyperactivity disorder. Epilepsy Behav. 2017, 75, 60-65. [CrossRef]

19. Endres, D.; Maier, S.; Feige, B.; Posielski, N.A.; Nickel, K.; Ebert, D.; Riedel, A.; Philipsen, A.; Perlov, E.; Tebartz van Elst, L. Altered Intermittent rhythmic delta and theta activity in the electroencephalographies of high functioning adult patients with autism spectrum disorder. Front. Hum. Neurosci. 2017, 11, 66. [CrossRef]

20. Turner, J.J.O. Hypercalcaemia-presentation and management. Clin. Med. 2017, 17, 270-273. [CrossRef]

21. Gairing, S.; Wiest, R.; Metzler, S.; Theodoridou, A.; Hoff, P. Fabry's disease and psychosis: Causality or coincidence? Psychopathology 2011, 44, 201-204. [CrossRef]

22. Grewal, R.P. Psychiatric disorders in patients with Fabry's disease. Int. J. Psychiatry Med. 1993, 23, $307-312$. [CrossRef]

23. Mahmud, H.M. Fabry's disease-a comprehensive review on pathogenesis, diagnosis and treatment. J. Pak. Med. Assoc. 2014, 64, 189-194. [PubMed]

24. Pierrot-Deseilligny, C.; Souberbielle, J.C. Vitamin D and multiple sclerosis: An update. Mult. Scler. Relat. Disord. 2017, 14, 35-45. [CrossRef] [PubMed]

25. Chiang, M.; Natarajan, R.; Fan, X. Vitamin D in Schizophrenia: A clinical review. Evid. Based Ment. Health 2016, 19, 6-9. [CrossRef]

26. Cao, B.; Wang, D.F.; Xu, M.Y.; Liu, Y.Q.; Yan, L.L.; Wang, J.Y.; Lu, Q.B. Lower folate levels in schizophrenia: A meta-analysis. Psychiatry Res. 2016, 245, 1-7. [CrossRef] [PubMed]

27. Hufschmidt, A.; Lücking, C.H.; Rauer, S. Neurologie Compact-Für Klinik und Praxis; Thieme: Stuttgart, Germany, 2013.

28. Sakuma, K.; Matsunaga, S.; Nomura, I.; Okuya, M.; Kishi, T.; Iwata, N. Folic acid/methylfolate for the treatment of psychopathology in schizophrenia: A systematic review and meta-analysis. Psychopharmacology 2018, 235, 2303-2314. [CrossRef]

29. Cai, L.; Chen, T.; Yang, J.; Zhou, K.; Yan, X.; Chen, W.; Sun, L.; Li, L.; Qin, S.; Wang, P.; et al. Serum trace element differences between Schizophrenia patients and controls in the Han Chinese population. Sci. Rep. 2015, 5, 15013. [CrossRef]

30. Winther, K.H.; Bonnema, S.J.; Hegedüs, L. Is selenium supplementation in autoimmune thyroid diseases justified? Curr. Opin. Endocrinol. Diabetes Obes. 2017, 24, 348-355. [CrossRef] 
31. Grain, R.; Lally, J.; Stubbs, B.; Malik, S.; LeMince, A.; Nicholson, T.R.; Murray, R.M.; Gaughran, F. Autoantibodies against voltage-gated potassium channel and glutamic acid decarboxylase in psychosis: A systematic review, meta-analysis, and case series. Psychiatry Clin. Neurosci. 2017, 71, 678-689. [CrossRef]

32. Dalmau, J.; Geis, C.; Graus, F. Autoantibodies to synaptic receptors and neuronal cell surface proteins in autoimmune diseases of the central nervous system. Physiol. Rev. 2017, 97, 839-887. [CrossRef]

33. Fernandes, B.S.; Steiner, J.; Bernstein, H.G.; Dodd, S.; Pasco, J.A.; Dean, O.M.; Nardin, P.; Gonçalves, C.A.; Berk, M. C-reactive protein is increased in schizophrenia but is not altered by antipsychotics: Meta-analysis and implications. Mol. Psychiatry 2016, 21, 554-564. [CrossRef]

34. Leffler, J.; Bengtsson, A.A.; Blom, A.M. The complement system in systemic lupus erythematosus: An update. Ann. Rheum. Dis. 2014, 73, 1601-1606. [CrossRef] [PubMed]

35. Lüngen, E.M.; Maier, V.; Venhoff, N.; Salzer, U.; Dersch, R.; Berger, B.; Riering, A.N.; Nickel, K.; Fiebich, B.L.; Süß, P.; et al. Systemic lupus erythematosus with isolated psychiatric symptoms and antinuclear antibody detection in the cerebrospinal fluid. Front. Psychiatry 2019, 10, 226. [CrossRef] [PubMed]

36. Sekar, A.; Bialas, A.R.; de Rivera, H.; Davis, A.; Hammond, T.R.; Kamitaki, N.; Tooley, K.; Presumey, J.; Baum, M.; Van Doren, V.; et al. Schizophrenia risk from complex variation of complement component 4. Nature 2016, 530, 177-183. [CrossRef] [PubMed]

37. Lee, S.H.; Byrne, E.M.; Hultman, C.M.; Kähler, A.; Vinkhuyzen, A.A.; Ripke, S.; Andreassen, O.A.; Frisell, T.; Gusev, A.; Hu, X.; et al. New data and an old puzzle: The negative association between schizophrenia and rheumatoid arthritis. Int. J. Epidemiol. 2015, 44, 1706-1721. [CrossRef]

38. Sturgeon, J.A.; Finan, P.H.; Zautra, A.J. Affective disturbance in rheumatoid arthritis: Psychological and disease-related pathways. Nat. Rev. Rheumatol. 2016, 12, 532-542. [CrossRef]

39. Hoirisch-Clapauch, S.; Amaral, O.B.; Mezzasalma, M.A.; Panizzutti, R.; Nardi, A.E. Dysfunction in the coagulation system and Schizophrenia. Transl. Psychiatry 2016, 6, e704. [CrossRef]

40. Regina, P.; Pnina, R.; Natur, A.; Yair, L. Anti-phospholipid syndrome associated with schizophrenia description of five patients and review of the literature. Immunol. Res. 2017, 65, 438-446. [CrossRef]

41. Sæther, S.G.; Rø, A.D.B.; Larsen, J.B.; Vaaler, A.; Kondziella, D.; Reitan, S.K. Biomarkers of autoimmunity in acute psychiatric disorders. J. Neuropsychiatry Clin. Neurosci. 2019, 31, 246-253. [CrossRef]

42. Mahler, M.; Andrade, L.E.; Casiano, C.A.; Malyavantham, K.; Fritzler, M.J. Anti-DFS70 antibodies: An update on our current understanding and their clinical usefulness. Expert. Rev. Clin. Immunol. 2019, 15, 241-250. [CrossRef]

43. Jarius, S.; Ruprecht, K.; Kleiter, I.; Borisow, N.; Asgari, N.; Pitarokoili, K.; Pache, F.; Stich, O.; Beume, L.A.; Hümmert, M.W.; et al. In cooperation with the neuromyelitis optica study group (NEMOS). MOG-IgG in NMO and related disorders: A multicenter study of 50 patients. Part 2: Epidemiology, clinical presentation, radiological and laboratory features, treatment responses, and long-term outcome. J. Neuroinflammation 2016, 13, 280.

44. Bechter, K. CSF diagnostics in psychiatry-present status-future projects. Neurol. Psychiatry Brain Res. 2016, 22, 69-74. [CrossRef]

45. Reiber, H. Proteins in cerebrospinal fluid and blood: Barriers, CSF flow rate and source-related dynamics. Restor. Neurol. Neurosci. 2003, 21, 79-96. [PubMed]

46. Bechter, K.; Reiber, H.; Herzog, S.; Fuchs, D.; Tumani, H.; Maxeiner, H.G. Cerebrospinal fluid analysis in affective and schizophrenic spectrum disorders: Identification of subgroups with immune responses and blood-CSF barrier dysfunction. J. Psychiatr. Res. 2010, 44, 321-330. [CrossRef]

47. Orlovska-Waast, S.; Köhler-Forsberg, O.; Brix, S.W.; Nordentoft, M.; Kondziella, D.; Krogh, J.; Benros, M.E. Cerebrospinal fluid markers of inflammation and infections in schizophrenia and affective disorders: A systematic review and meta-analysis. Mol. Psychiatry 2019, 24, 869-887. [CrossRef] [PubMed]

48. Najjar, S.; Pahlajani, S.; De Sanctis, V.; Stern, J.N.H.; Najjar, A.; Chong, D. Neurovascular unit dysfunction and blood-brain barrier hyperpermeability contribute to Schizophrenia neurobiology: A theoretical integration of clinical and experimental evidence. Front. Psychiatry 2017, 8, 83. [CrossRef]

49. Pollak, T.A.; Drndarski, S.; Stone, J.M.; David, A.S.; McGuire, P.; Abbott, N.J. The blood-brain barrier in psychosis. Lancet Psychiatry 2018, 555, 79-92. [CrossRef]

50. Oviedo-Salcedo, T.; de Witte, L.; Kümpfel, T.; Kahn, R.S.; Falkai, P.; Eichhorn, P.; Luykx, J.; Hasan, A. Absence of cerebrospinal fluid antineuronal antibodies in schizophrenia spectrum disorders. Br. J. Psychiatry 2018, 212, 318-320. [CrossRef] 
51. Endres, D.; Perlov, E.; Feige, B.; Fleck, M.; Bartels, S.; Altenmüller, D.M.; Tebartz van Elst, L. Electroencephalographic findings in schizophreniform and affective disorders. Int. J. Psychiatry Clin. Pr. 2016, 20, 157-164. [CrossRef]

52. Tebartz van Elst, L.; Krishnamoorthy, E.S.; Schulze-Bonhage, A.; Altenmüller, D.M.; Richter, H.; Ebert, D.; Feige, B. Local area network inhibition: A model of a potentially important paraepileptic pathomechanism in neuropsychiatric disorders. Epilepsy Behav. 2011, 22, 231-239. [CrossRef]

53. Najjar, S.; Pearlman, D.M. Neuroinflammation and white matter pathology in schizophrenia: Systematic review. Schizophr. Res. 2015, 161, 102-112. [CrossRef]

54. Sachdev, P.; Chen, X.; Wen, W. White matter hyperintensities in mid-adult life. Curr. Opin. Psychiatry 2008, 21, 268-274. [CrossRef] [PubMed]

55. Gur, R.E.; Kaltman, D.; Melhem, E.R.; Ruparel, K.; Prabhakaran, K.; Riley, M.; Yodh, E.; Hakonarson, H.; Satterthwaite, T.; Gur, R.C. Incidental findings in youths volunteering for brain MRI research. AJNR Am. J. Neuroradiol. 2013, 34, 2021-2025. [CrossRef] [PubMed]

56. Jiang, X.; Chen, Y.; Zhou, Z.; Luo, L.; Hu, W.; Zheng, H.; Zhu, Z.; Wang, J.; Chen, Z. Surgical resection of pineal epidermoid cyst contributed to relieving schizophrenia symptoms. World Neurosurg. 2018, 113, 304-307. [CrossRef] [PubMed]

57. Benros, M.E.; Nielsen, P.R.; Nordentoft, M.; Eaton, W.W.; Dalton, S.O.; Mortensen, P.B. Autoimmune diseases and severe infections as risk factors for schizophrenia: A 30-year population-based register study. Am. J. Psychiatry 2011, 168, 1303-1310. [CrossRef] [PubMed]

58. Benros, M.E.; Pedersen, M.G.; Rasmussen, H.; Eaton, W.W.; Nordentoft, M.; Mortensen, P.B. A nationwide study on the risk of autoimmune diseases in individuals with a personal or a family history of schizophrenia and related psychosis. Am. J. Psychiatry 2014, 171, 218-226. [CrossRef] [PubMed]

59. Benros, M.E.; Eaton, W.W.; Mortensen, P.B. The epidemiologic evidence linking autoimmune diseases and psychosis. Biol. Psychiatry 2014, 75, 300-306. [CrossRef]

60. Endres, D.; Huzly, D.; Dersch, R.; Stich, O.; Berger, B.; Schuchardt, F.; Perlov, E.; Venhoff, N.; Hellwig, S.; Fiebich, B.L.; et al. Do patients with schizophreniform and bipolar disorders show an intrathecal, polyspecific, antiviral immune response? A pilot study. Fluids Barriers CNS 2017, 14, 34. [CrossRef]

61. Jézéquel, J.; Rogemond, V.; Pollak, T.; Lepleux, M.; Jacobson, L.; Gréa, H.; Iyegbe, C.; Kahn, R.; McGuire, P.; Vincent, A.; et al. Cell-and single molecule-based methods to detect Anti-N-Methyl-D-aspartate receptor autoantibodies in patients with first-episode psychosis from the OPTiMiSE project. Biol. Psychiatry 2017, 82, 766-772. [CrossRef] 